\title{
Effect of Sucralose and Maltitol on the Physicochemical Properties of Dietetic Frozen Bifido Yoghurt
}

\author{
A. Elango ${ }^{1 *}$, D. Vijaya ${ }^{1}$, V. Jayalalitha ${ }^{2}$ and T.R. Pugazhenthi ${ }^{3}$ \\ ${ }^{1}$ Department of Veterinary Public Health and Epidemiology, Madras Veterinary College, \\ Tamil Nadu Veterinary and Animal Sciences University, Chennai-600 007, Tamil Nadu, India \\ ${ }^{2}$ Veterinary University Training and Research Centre, Tiruchirapalli-620023, Tamil Nadu, India \\ ${ }^{3}$ Department of Livestock Products Technology (Dairy Science), Madras Veterinary College, \\ Chennai-600 007, Tamil Nadu, India \\ *Corresponding author
}

\begin{tabular}{|c|c|}
\hline & A B S T R A C T \\
\hline & \multirow{6}{*}{$\begin{array}{l}\text { Frozen yogurt is a unique dessert with physical properties of ice cream, and nutritional and } \\
\text { sensory characteristics of yoghurt. A study was carried out to prepare dietetic frozen } \\
\text { yoghurt by incorporating two per cent of traditional yoghurt cultures and } 1 \% \\
\text { Bifidobacterium bifidum culture and also by replacing sugar with artificial sweeteners viz., } \\
\text { sucralose and maltitol. Six types of frozen yoghurt mixes prepared with sugar, } 50 \text { per cent } \\
\text { sucralose, } 100 \text { per cent sucralose, } 50 \text { per cent maltitol, } 100 \text { per cent maltitol and a } \\
\text { combination of sucralose and maltitol }(50 \% \text { : } 50 \% \text { ) were designated as FYM0, FYM1, } \\
\text { FYM2, FYM3, FYM4 and FYM5 and were subjected to determination of physicochemical } \\
\text { properties. The pH and titratable acidity of frozen yoghurt mixes increased as the level of } \\
\text { substitution of sucralose increased. No significant (P>0.05) difference was observed in } \\
\text { other properties such as specific gravity, viscosity, melting time, over run values between } \\
\text { different frozen yoghurt mixes. The frozen yoghurt mixes with } 50 \text { per cent sucralose } \\
\text { (FYM1) recorded the highest overall acceptability next to control frozen yoghurt mix. A } \\
\text { end of } 5 \text { weeks of storage the count of yoghurt bacteria and B. bifidum were } 6.0147 \pm \\
0.005 \text { and } 5.2626 \pm 0.012 \text { respectively. It is concluded that, except for pH and acidity, } \\
\text { varying levels of substitution of these artificial sweeteners did not affect the physico } \\
\text { chemical properties of different frozen yoghurt mixes. }\end{array}$} \\
\hline & \\
\hline $\begin{array}{l}\text { Yoghurt, Dietetic, } \\
\text { Frozen, Sucralose, } \\
\text { Maltitol. }\end{array}$ & \\
\hline Article Info & \\
\hline $\begin{array}{l}\text { Accepted: } \\
\text { 10 September } 2017 \\
\text { Available Online: } \\
10 \text { October } 2017\end{array}$ & \\
\hline & \\
\hline
\end{tabular}

\section{Introduction}

Frozen yoghurt can be regarded as a healthy alternative to ice cream for people suffering from obesity, cardiovascular diseases and lactose intolerance due to its low fat content and reduced lactose concentration. It is a complex fermented frozen dairy dessert that combines the physical characteristics of ice cream with sensory and nutritional properties of fermented milk products. It is often consumed by lactose-sensitive people in place of ice cream, as the live cultures can help to digest the lactose.

Incorporation of probiotic bacteria into fermented dairy products is gaining popularity for their health benefits, e.g. improvements in lactose digestion, prevention of intestinal infections, suppression of carcinogenesis and 
reduction of serum cholesterol concentrations (Davidson et al., 2000; De and Schrezenmeir 2008). Probiotics play a major role in health and wellbeing beyond basic nutrition (Vanaja et al., 2011). The calorific values of different dietetic yoghurts sweetened with various sweeteners (aspartame, fructose and sucralose) were lower than the product sweetened with sucrose (Fonseca and Neves, 1998). Similar to western countries, Indian consumers are also becoming health conscious and tending to avoid sweets with high sugar content. In the modern context, more and more people choose low sugar for health reasons owing to prevailing diabetic conditions or motivated by calorie consciousness. Considering the above facts in this investigation, an attempt has been made to prepare a refreshing, tangy dietetic dessert that combines the physical characteristics of ice cream with sensory and nutritional properties of yoghurt and the result of the physicochemical analyses of the developed is presented in this article.

\section{Materials and Methods}

\section{Preparation of dietetic frozen bifido yoghurt}

The frozen yoghurt was prepared as per the procedure outlined by Guven and Karaca (2002). Six lots were prepared using fresh skim milk which was taken in a stainless steel vessel. Skim milk powder at the rate of 4 per cent $(\mathrm{w} / \mathrm{v})$ and sugar at the rate of 15 per cent $(\mathrm{w} / \mathrm{v})$ were added to it and homogenized at 1000 psi. The contents were mixed well and pasteurized at $85^{\circ} \mathrm{C}$ for 30 minutes, cooled to room temperature and inoculated with 2 per cent of yoghurt cultures containing Lactobacillus delbrueckii ssp. bulgaricus, and Streptococcus salivarius ssp. thermophilus (Chr. Hansen, Denmark) and 1\% Bifidobacterium bifidum culture (NDRI, Karnal). It was then mixed well and incubated at $42^{\circ} \mathrm{C}$ for 2 to 3 hours. Afterwards the coagulum was broken and to this 0.3 per cent carboxy methyl cellulose (CMC) as stabilizer and 0.3 per cent glycerol mono stearate (GMS) as emulsifier was added. The flavor was added to the mix before freezing. The mix was thoroughly mixed and then frozen in an ice cream freezer and drawn from the freezer at $-4^{\circ} \mathrm{C}$ and packed in $100 \mathrm{ml}$ cups and hardened at $-20^{\circ} \mathrm{C}$.

\section{Different types of frozen yoghurt mixes}

The sugar was replaced by artificial sweeteners viz., sucralose (Sugar free NaturaCadila Health Care Liimited, Ahemedabad, India) and maltitol (Titan Biotech ltd, Bhiwadi, Rajasthan, India) at different levels for the following experimental design which is also given comprehensively in Table 1 .

FYM0-Frozen yoghurt mix with sugar (control)

FYM1- Frozen yoghurt mix with 50 per cent of sucralose

FYM2- Frozen yoghurt mix with 100 per cent of sucralose

FYM3- Frozen yoghurt mix with 50 per cent of maltitol

FYM4- Frozen yoghurt mix with 100 per cent of maltitol

FYM5- Frozen yoghurt mix with a combination of sucralose and maltitol (50\%:50\%)

\section{Physico chemical analyses of dietetic frozen} yoghurt

Acidity was estimated as per the procedure described in IS: SP: 18 (part XI)-1981 and pH was estimated by digital $\mathrm{pH}$ meter. The 
specific gravity of frozen yoghurt was estimated by gravimetric method using specific gravity bottle. Melting time and over run was estimated by the procedure outlined by Guven and karaca (2002)

Volume of frozen yoghurt Volume of frozen yoghurt mix

Over run $=$

Volume of frozen yoghurt mix

\section{Estimation of viscosity (Pipette method)}

Mark A and B on the $10 \mathrm{cc}$ pipette. The viscosity of the frozen yoghurt mix was determined by comparing the flow of frozen yoghurt mix and water through the pipette. (Water is taken in as the reference liquid). Fill up the pipette with frozen yoghurt mix up to ' $A$ ' mark and keep the pipette vertically. Start the stop clock when the level of the frozen yoghurt mix crosses the A mark. Find out the time taken for the frozen yoghurt mix to flow from the mark A to B mark. In the same manner take water in the pipette as before and find out the time of flow of water from the mark A to B. Using the RV formula, the viscosity of frozen yoghurt mix was calculated by using the viscosity of water as $1.005 \mathrm{cp}$.

$\begin{array}{lr}\mathrm{n}_{\mathrm{o}} & \mathrm{t}_{\mathrm{o}} \mathrm{p}_{\mathrm{o}} \\ --- & \mathrm{n}_{1} \\ \mathrm{t}_{1} \mathrm{p}_{1}\end{array}$

$\mathrm{n}_{\mathrm{o}}-$ Viscosity of water in $\mathrm{CP}$

$\mathrm{n}_{1}-$ Viscosity of frozen yoghurt mix

$t_{1}$ - Time of flow of frozen yoghurt mix

$$
\mathrm{n}_{1}=\text { no } \frac{\mathrm{t}_{\mathrm{o}} \mathrm{p}_{\mathrm{o}}}{-\mathrm{t}_{1} \mathrm{p}_{1}}
$$

$\mathrm{t}_{\mathrm{o}}$ - Time of flow of water

$\mathrm{p}_{\mathrm{o}}-\mathrm{Sp}$. gravity of water

$\mathrm{p}_{1}-\mathrm{Sp}$. gravity of frozen yoghurt mix

\section{Results and Discussion}

Physico chemical properties of different frozen yoghurt mixes during storage period

\section{Titratable acidity}

Table 2 shows the mean \pm SE values of titratable acidity in different frozen yoghurt mixes (FYM0, FYM1, FYM2, FYM3, FYM4 and FYM5) during storage period of $0,1,2,3$, 4 and 5 weeks at $-20^{\circ} \mathrm{C}$. The mean $\pm \mathrm{SE}$ values of titrable acidity in different frozen yoghurt mixes were $0.4409 \pm 0.0046,0.4462$ $\pm 0.0046,0.4498 \pm 0.0043,0.4408 \pm 0.0045$, $0.4398 \pm 0.0043$ and $0.4459 \pm 0.0046$ respectively. Statistical analysis showed a highly significant $(\mathrm{P}<0.01)$ difference in titratable acidity values between different frozen yoghurt mixes and no significant $(\mathrm{P}>$ $0.05)$ difference in titratable acidity values between different storage periods.

\section{pH}

Table 3 shows the mean $\pm \mathrm{SE}$ values of $\mathrm{pH}$ in different frozen yoghurt mixes (FYM0, FYM1, FYM2, FYM3, FYM4 and FYM5) during storage period of $0,1,2,3,4$ and 5 weeks at $-20^{\circ} \mathrm{C}$. The mean $\pm \mathrm{SE}$ values of $\mathrm{pH}$ in different frozen yoghurt mixes were 5.3269 $\pm 0.0094,5.3380 \pm 0.0108,5.4796 \pm 0.0033$, $5.3278 \pm 0.0107,5.3278 \pm 0.0111$ and 5.3385 \pm 0.0108 respectively. Statistical analysis showed a highly significant $(\mathrm{P}<0.01)$ difference in $\mathrm{pH}$ values between different frozen yoghurt mixes and no significant $(\mathrm{P}>0.05)$ difference in $\mathrm{pH}$ values between different storage periods.

\section{Specific gravity, viscosity, melting time and overrun}

Table 4 shows the mean \pm SE values of specific gravity, viscosity, melting time and over run in different frozen yoghurt mixes 
(FYM0, FYM1, FYM2, FYM3, FYM4 and FYM5). The mean \pm SE values of specific gravity in different frozen yoghurt mixes were $1.0535 \pm 0.001,1.0533 \pm 0.001,1.0536 \pm$ $0.001,1.0534 \pm 0.001,1.0535 \pm 0.001$ and $1.0536 \pm 0.001$ respectively. The mean $\pm \mathrm{SE}$ values of viscosity in different frozen yoghurt mixes were $34.454 \pm 0.008,34.456 \pm 0.007$, $34.489 \pm 0.020,34.456 \pm 0.004,34.455 \pm$ 0.009 and $34.456 \pm 0.009$ respectively.
The mean \pm SE values of melting time in different frozen yoghurt mixes were $57.607 \pm$ $0.082,57.608 \pm 0.082,57.607 \pm 0.082,57.606$ $\pm 0.082,57.607 \pm 0.082$ and $57.607 \pm 0.082$ respectively.

The mean over run values of different frozen yoghurt mixes were $24.512 \pm 0.760,24.167 \pm$ $0.600,24.00 \pm 0.577,24.166 \pm 0.600,24.500$ \pm 0.765 and $24.501 \pm 0.428$ respectively.

Flow diagram of preparation of dietetic frozen yoghurt

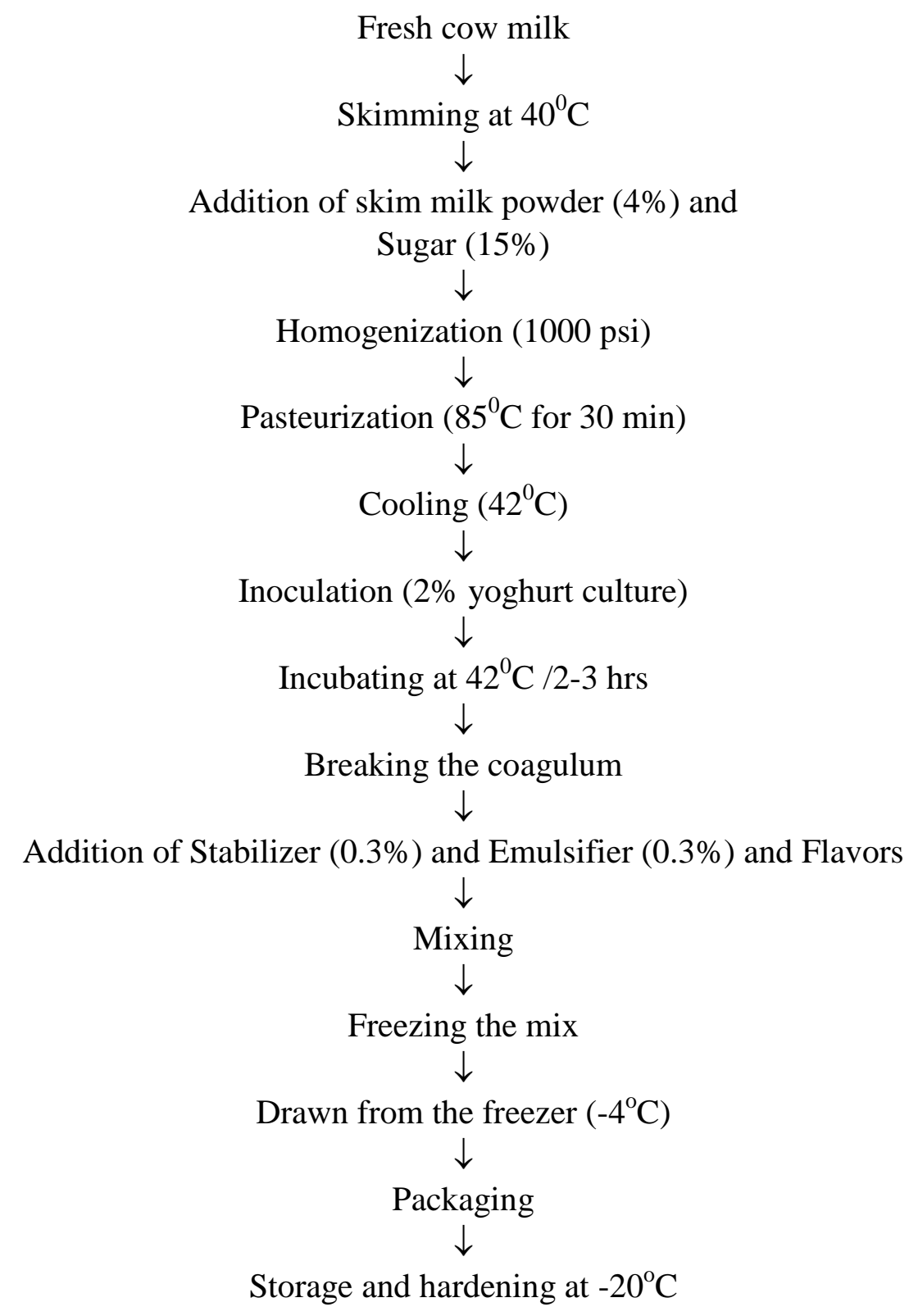


Table.1 Ingredients used per litre of different frozen yoghurt mixes

\begin{tabular}{|c|c|c|c|c|c|c|c|c|}
\hline $\begin{array}{l}\text { Types of Frozen } \\
\text { yoghurt mixes }\end{array}$ & $\begin{array}{c}\text { Percentage Substitution } \\
\text { level of sweeteners }\end{array}$ & $\begin{array}{c}\text { Skim Milk } \\
(\mathrm{ml})\end{array}$ & SMP (g) & Sugar $(g)$ & Artificial sweeteners & $\begin{array}{c}\text { Yoghurt \& bifido } \\
\text { cultures }(\mathrm{ml})\end{array}$ & $\begin{array}{c}\text { Stabilizer \& } \\
\text { Emulsifier (g) }\end{array}$ & $\begin{array}{c}\text { Flavor } \\
(\mathbf{m l})\end{array}$ \\
\hline FYM0 & 0 & 900 & 40 & 150 & - & 30 & 6 & 3 \\
\hline FYM1 & 50 & 900 & 40 & 75 & 11sugar free Natura pellets & 30 & 6 & 3 \\
\hline FYM3 & 50 & 900 & 40 & 75 & 75 & 30 & 6 & 3 \\
\hline FYM4 & 100 & 900 & 40 & - & 150 & 30 & 6 & 3 \\
\hline FYM5 & $50+50$ & 900 & 40 & - & $75 \mathrm{~g}$ Maltitol +11 pellets & 30 & 6 & 3 \\
\hline
\end{tabular}

Table.2 Titratable acidity of different frozen yoghurt mixes during storage period (Mean \pm SE) ${ }^{@}$

\begin{tabular}{|c|c|c|c|c|c|c|c|}
\hline Storage / FY Mixes & 0 week & 1 week & 2 weeks & 3 weeks & 4 weeks & 5 weeks & Mean \pm SE \\
\hline FYM0 & 0.433 & 0.431 & 0.433 & 0.431 & 0.432 & 0.432 & $0.4409^{\mathrm{a}} \pm 0.0046$ \\
\hline FYM1 & 0.443 & 0.442 & 0.443 & 0.440 & 0.442 & 0.445 & $0.4462^{\mathrm{b}} \pm 0.0046$ \\
\hline FYM2 & 0.468 & 0.469 & 0.469 & 0.466 & 0.465 & 0.459 & $0.4498^{\mathrm{c}} \pm 0.0043$ \\
\hline FYM3 & 0.433 & 0.433 & 0.432 & 0.432 & 0.434 & 0.433 & $0.4408^{\mathrm{a}} \pm 0.0045$ \\
\hline FYM4 & 0.433 & 0.432 & 0.433 & 0.434 & 0.434 & 0.433 & $0.4398^{\mathrm{a}} \pm 0.0043$ \\
\hline FYM5 & 0.443 & 0.443 & 0.444 & 0.445 & 0.443 & 0.443 & $0.4459^{\mathrm{b}} \pm 0.0046$ \\
\hline
\end{tabular}

Table $3 \mathrm{pH}$ of different frozen yoghurt mixes during storage period (Mean $\pm \mathrm{SE}){ }^{@}$

\begin{tabular}{|c|c|c|c|c|c|c|c|}
\hline Storage / FY Mixes & O week & 1 week & 2 weeks & 3 weeks & 4 weeks & 5 weeks & Mean \pm SE \\
\hline FYM0 & 5.314 & 5.314 & 5.312 & 5.315 & 5.313 & 5.314 & $5.3269^{\mathrm{a}} \pm 0.0094$ \\
\hline FYM1 & 5.331 & 5.334 & 5.334 & 5.332 & 5.331 & 5.331 & $5.3380^{\mathrm{b}} \pm 0.0108$ \\
\hline FYM2 & 5.476 & 5.481 & 5.471 & 5.472 & 5.481 & 5.484 & $5.4796^{\mathrm{C}} \pm 0.0033$ \\
\hline FYM3 & 5.315 & 5.317 & 5.314 & 5.314 & 5.313 & 5.313 & $5.3278^{\mathrm{a}} \pm 0.0107$ \\
\hline FYM4 & 5.318 & 5.316 & 5.315 & 5.313 & 5.315 & 5.313 & $5.3278^{\mathrm{a}} \pm 0.0111$ \\
\hline FYM5 & 5.332 & 5.331 & 5.334 & 5.332 & 5.331 & 5.331 & $5.3385^{b} \pm 0.0108$ \\
\hline
\end{tabular}

Table.4 Physico chemical properties of different frozen yoghurt mixes (Mean \pm SE) ${ }^{@}$

\begin{tabular}{|c|c|c|c|c|c|c|c|}
\hline Properties & FYM0 & FYM1 & FYM2 & FYM3 & FYM4 & FYM5 & F value \\
\hline Specific gravity & $1.0535^{\mathrm{a}} \pm 0.001$ & $1.0533^{\mathrm{a}} \pm 0.001$ & $1.0536^{\mathrm{a}} \pm 0.001$ & $1.0534^{\mathrm{a}} \pm 0.001$ & $1.0535^{\mathrm{a}} \pm 0.001$ & $1.0536^{\mathrm{a}} \pm 0.001$ & $1.06^{\mathrm{NS}}$ \\
\hline Viscosity (centipoises) & $34.454^{\mathrm{a}} \pm 0.008$ & $34.456^{\mathrm{a}} \pm 0.007$ & $34.489^{\mathrm{a}} \pm 0.020$ & $34.456^{\mathrm{a}} \pm 0.004$ & $34.455^{\mathrm{a}} \pm 0.009$ & $34.456^{\mathrm{a}} \pm 0.009$ & $2.48^{\mathrm{NS}}$ \\
\hline Meltdown (minutes) & $57.607^{\mathrm{a}} \pm 0.082$ & $57.608^{a} \pm 0.082$ & $57.607^{\mathrm{a}} \pm 0.082$ & $57.606^{\mathrm{a}} \pm 0.082$ & $57.607^{\mathrm{a}} \pm 0.082$ & $57.607^{\mathrm{a}} \pm 0.082$ & $0.16^{\mathrm{NS}}$ \\
\hline Overrun(per cent) & $24.512^{\mathrm{a}} \pm 0.760$ & $24.167^{\mathrm{a}} \pm 0.600$ & $24.00^{\mathrm{a}} \pm 0.577$ & $24.166^{\mathrm{a}} \pm 0.600$ & $24.500^{\mathrm{a}} \pm 0.763$ & $24.501^{\mathrm{a}} \pm 0.428$ & $1.06^{\mathrm{NS}}$ \\
\hline
\end{tabular}


Physico chemical properties of different frozen yoghurt mixes during storage period

\section{Titratable acidity}

There was no significant $(\mathrm{P}>0.05)$ difference in titratable acidity values between storage period of $0,1,2,3,4$ and 5 weeks. This was in conformity with the findings of Baig and Prasad (1996). He indicated that the titratable acidity and $\mathrm{pH}$ in frozen yoghurt during storage at $-20^{\circ} \mathrm{C}$ for 90 days almost remained constant. This indicates that there was no biochemical activity by starter bacteria during storage of the product at $-20^{\circ} \mathrm{C}$. There was a highly significant difference $(\mathrm{P}<0.01)$ in titratable acidity values between different frozen yoghurt mixes. The frozen yoghurt mix with 100 per cent sucralose (FYM2) recorded higher titratable acidity values among all other mixes. The frozen yoghurt mix with 50 per cent sucralose (FYM1) and the mix with a combination of sucralose and maltitol (FYM5) recorded higher titratable acidity values next to the frozen yoghurt mix with 100 per cent sucralose (FYM2). There was no much difference in titratable acidity values of mixes with sugar (FYM0) and maltitol (FYM3 and FYM4). These findings indicate that as the concentration of sucralose increased, there was an increase in titratable acidity. This resembled the findings of Marshall et al., (2003), who recorded that, as the level of substitution of the high intensity sweetener sucralose increased, their titratable acidity and $\mathrm{pH}$ values were also increased. This might be attributed to the chloride radicals in the sucralose structure. These findings also indicate that the addition of maltitol in 50 per cent (FYM3) and 100 per cent (FYM4) did not induce any change in the acidity as compared with the sucralose. However, the titratable acidity values in different frozen yoghurt mixes fall within the range prescribed by Inoue et al., (1998), who opined that the ice cream type frozen yoghurt with titratable acidity of 0.4 to 0.5 per cent was the most preferred by the panellists.

\section{pH}

There was no significant $(\mathrm{P}>0.05)$ difference in $\mathrm{pH}$ values between different storage period of $0,1,2,3,4$ and 5 weeks. This was in accordance with the findings of Baig and Prasad (1996). There was a highly significant difference $(\mathrm{P}<0.01)$ in $\mathrm{pH}$ values between different frozen yoghurt mixes. The frozen yoghurt mix with 100 per cent sucralose (FYM2) recorded higher $\mathrm{pH}$ values among all other mixes. The frozen yoghurt mix with 50 per cent Sucralose (FYM1) and the mix with a combination of sucralose and maltitol (FYM5) recorded higher $\mathrm{pH}$ values next to the frozen yoghurt mix with 100 per cent sucralose (FYM2). There was no much difference in $\mathrm{pH}$ values of mixes with sugar (FYM0) and maltitol (FYM3 and FYM4).

These findings indicate that as the concentration of sucralose increased, there was an increase in $\mathrm{pH}$ values. These results agree with the findings of Marshall et al., (2003). The $\mathrm{pH}$ values of control frozen yoghurt mix (FYM0) and the frozen yoghurt mix with 50 (FYM3) and 100 per cent maltitol (FYM4) did not show much difference in $\mathrm{pH}$ values as compared to the sucralose. However the $\mathrm{pH}$ values in different frozen yoghurt mixes fall within the range prescribed by Inoue et al., (1998), who found that the ice cream type frozen yoghurt with $\mathrm{pH}$ of 5.0 to 5.5 was the most preferred by the panellists.

\section{Specific gravity}

There was no significant $(\mathrm{P}>0.05)$ difference in specific gravity values between different frozen yoghurt mixes. These findings were in close agreement with the findings of Vijayalakshmi (2005), who reported that the 
specific gravity of frozen yoghurt ranged from 1.056 to 1.086 .

\section{Viscosity}

There was no significant $(\mathrm{P}>0.05)$ difference in viscosity values between different frozen yoghurt mixes. The viscosity values between different frozen yoghurt mixes recorded in the study were slightly lower than the value obtained by Vijayalakshmi (2005), who found that the viscosity of frozen yoghurt ranged from 41.99 to 51.99 (centipoises) at an acidity of 0.7 per cent. The decrease in viscosity values of different frozen yoghurt mixes may be attributed to the fact that, the product with lower acidity will have the lower viscosity values (Ordonez et al., 2000).

\section{Melting time}

There was no significant $(\mathrm{P}>0.05)$ difference in melting time between different frozen yoghurt mixes. The melting times recorded in the study were in accordance with the findings of Vijayalakshmi (2005), who observed that the complete melting time of frozen yoghurt ranged from 57 to 80 minutes.

\section{Overrun}

There was no significant $(\mathrm{P}>0.05)$ difference in overrun values between different frozen yoghurt mixes. The overrun values recorded in the study were in accordance with the findings of Guven and Karaca (2002), who inferred that the overrun of vanilla frozen yoghurt ranged from 22.15 to 31.63 (per cent).

The frozen yoghurt mixes with 50 per cent sucralose (FYM1) recorded the highest overall acceptability scores next to control frozen yoghurt mix. The $\mathrm{pH}$ and titratable acidity of frozen yoghurt mixes increased as the level of substitution of sucralose increased. But they remained constant between different storage periods. Statistical analysis showed no significant $(\mathrm{P}>0.05)$ difference in other properties such as, specific gravity, viscosity, melting time, over run values between different frozen yoghurt mixes. The count of both yoghurt bacteria and Bifidobacterium bifidum did not differ significantly $(\mathrm{P}>0.05)$ between different frozen yoghurt mixes. A highly significant ( $\mathrm{P}$ $<0.01$ ) difference in the count of both yoghurt bacteria and Bifidobacterium bifidum was noticed between different storage periods at $-20^{\circ} \mathrm{C}$. The reduction in the count of yoghurt bacteria and $B$. bifidum was nearly 1 $\log$ units during the storage period. At end of 5 weeks of storage the count of yoghurt bacteria and B.bifidum were $6.0147 \pm 0.005$, $5.2626 \pm 0.012$ respectively. It is concluded that, except for $\mathrm{pH}$ and acidity, varying levels of substitution of these artificial sweeteners did not affect the physico chemical properties of different frozen bifido yoghurt mixes. As there is a growing interest among the health conscious consumers for food products that can provide health benefits, hopefully, the developed dietetic product with probiotic cultures will cater to their need.

\section{References}

Baig, M.L., and Prasad, V.1996. Biochemical, Microbiological and sensory characteristics of frozen yoghurt fortified with whey solids. Indian $\mathrm{J}$. Dairy Sci., 49(9): 585-592.

Davidson, R.H., Duncan S.E., Hackney C.R., Eigel W.N., and Boling J.W.2000. Probiotic culture survival and implications in fermented frozen yoghurt characteristics. J. Dairy Sci, 83:666-673.

De Vrese, M., and Schrezenmeir, J. 2008. Probiotics, prebiotics, and synbiotics. In: Food Biotechnology: Advances in Biochemical Engineering 
Biotechnology. Vol 111, pp. 1-66. Stahl U, Donalies UE, Nevoigt E (Eds). Verlag Berlin Heidelberg: Springer.

Fonseca, R.R., and Neves R.C.A., 2005. Elaboraco de iogurte dietetico de graviola.In $16^{\text {th }}$ Congress Brasieleiro de Clencia e Technologia de Alimentos (1998). Cited by Pinheiro M.V.S., Oliveira M.N., Penna A.L.B., Tamime A.Y., The effect of different sweeteners in low calorie yoghurts-a review, Int. J. Dairy Technol., 58(4): 193-199.

Guven, M., and Karaca O.B. 2002. The effects of varying sugar content and fruit concentration on the physical properties of vanilla and fruit icecream- type frozen yoghurts. Int. J. Dairy Technol. 55(1):27-30.

Inoue, K., Shota, K., and Ito, T.1998. Preparation and properties of ice cream type frozen yogurt. Int. J. Dairy
Technol. 51(2):44-50.

Marshall, R.T., Goff H.D., and Hartel R.W.2003. Ice Cream, 6th edn. New York: Aspen Publishers.

Ordonez, G.A., Jeon, I.J., and Roberts H.A. 2000. Manufacture of frozen yoghurt with ultrafiltered milk and probiotic lactic acid bacteria. J. Fd. Process. Preserv. 24(2) (2000)163-176.

Vanaja, G., Gotcheva, V., Angelov. A., and Agrawal, R.2011. Formation of volatiles and fatty acids of therapeutic importance in the probiotic Lactobacillus plantarum LPcfr adapted to resist GIT conditions. J. Food Sci. Technol., 48(1):110-113.

Vijayalakshmi, R., Yoghurt like product with probiotic cultures. Ph.D., thesis submitted to Tamil Nadu Veterinary and Animal Sciences University, Chennai (2005).

\section{How to cite this article:}

Elango, A., D. Vijaya, V. Jayalalitha and Pugazhenthi, T.R. 2017. Effect of Sucralose and Maltitol on the Physicochemical Properties of Dietetic Frozen Bifido Yoghurt. Int.J.Curr.Microbiol.App.Sci. 6(10): 1036-1043. doi: https://doi.org/10.20546/ijcmas.2017.610.125 